\title{
PPM USAHA MIKRO GETHUK DI DUSUN KEDUNGSEKAR LOR DESA KEDUNGSEKAR KECAMATAN BENJENG KABUPATEN GRESIK
}

\author{
Aminatuzzuhro ${ }^{1}$, Prita Anugrah Widowati ${ }^{2}$, Dwi Prihantono ${ }^{3}$ \\ ${ }^{1,2,3}$ Universitas Wijaya Putra \\ aminatuzzuhro@uwp.ac.ic,prita@uwp.ac.id,dwiprihantono@uwp.ac.id
}

\begin{abstract}
Abstrak
Usaha mikro gethuk yang menjadi mitra dalam Program Pemberdayaan Masyarakat ini berdomisili di Dusun Kedungsekar Lor Desa Kedungsekar Kecamatan Benjeng Kabupaten Gresik. Permasalahan yang dihadapi mitra antara lain: (1) Peralatan yang digunakan oleh mitra menggunakan peralatan manual; (2) Bak untuk bahan dan bahan setengah jadi masih menggunakan plastik; (3) Tidak menggunakan alat pelindung diri yang sehat untuk makanan; (4) Proses produksi masih dilakukan di lantai beralaskan tikar; (5) Lingkungan tempat produksi juga kurang bersih dan dekat dengan tempat cuci piring dan kamar mandi; (6) Pengemasan produk juga masih sederhana dengan box karton untuk yang roll gethuk dan kertas minyak untuk yang dijual eceran / potongan; (8) Mitra sampai saat ini masih belum mencatat semua transaksi harian yang sudah dilakukan; (9) Perencanaan produksi juga belum dilakukan atau hanya berdasarkan permintaan Metode pelaksanaan program, yaitu melalui penyelenggaraan pelatihan dan pendampingan produksi sehat, pembuatan label dan kemasan yang sehat dan aman serta inovasi produk untuk makanan; Pengadaan peralatan pelindung diri untuk produksi makanan; Pengadaan bak stainless steel; dan pencatatan keuangan usaha mikro, perencanaan produksi dan inovasi produk. Hasil pelaksanaan program antara lain; (1) Memberikan pelatihan dan pendampingan produksi sehat, pencatatan keuangan, dan pemanfaatan media sosial untuk pemasaran; (2) pengadaan peralatan produksi yang sehat; dan (3) pembuatan kemasan produk.
\end{abstract}

Kata Kunci : Gethuk, Manajemen Usaha, Pemberdayaan, Produksi,

\section{PENDAHULUAN}

Gethuk merupakan makan tradisonal yang umum bagi masyarakat Jawa namun masih digemari terutama oleh masyarakat pedesaan karena tidak mengandung pengawet atau bahan kimia seperti pada makanan-makanan modern. Usaha mikro gethuk yang menjadi sasaran Program Pemberdayaan masyarakat ini dikelola oleh Ibu Rika yang berdomisili di Dusun Kedungsekar Lor Desa Kedungsekar Kecamatan Benjeng Kabupaten Gresik. Desa ini terletak 19 KM sebelah selatan
Pusat Kabupaten Gresik dan 3.5 KM ke Kantor Kecamatan Benjeng. Desa Kedungsekar memiliki luar $2,1 \mathrm{KM}^{2}$. Jumlah penduduk Desa Kedungsekar sebanyak 3.650 jiwa, dimana 1.828 laki-laki dan 1.822 perempuan. Desa ini juga merupakan desa yang memiliki industri yang tergolong tinggi di Kecamatan Benjeng yaitu berjumlah 280 industri kecil dan 1 industri sedang (BPS Kabupaten Gresik, 2019). Industri-industri inilah yang menopang perekonomian sebagian besar warga Desa Kedungsekar. Pemilihan mitra ini dipandang didasarkan pada kondisi usaha mitra yang masih 
sederhana dan membutuhkan pendampingan baik dari sisi manajemen maupun teknologi.

Usaha mikro yang dijalankan mitra berawal dari usaha sampingan dan coba-coba namun saat ini merupakan usaha utama dan dirasa memiliki potensi untuk berkembang. Bahan baku utama produk gethuk adalah Singkong. Seperti diketahui, Singkong (Manihot utilissima) merupakan salah satu bahan pangan pengganti beras yang cukup populer di Indonesia dan dinilai penting dalam perannya menopang ketahanan pangan. Produksi singkong tahun 2018 mencapai 19,3 juta ton, dimana 13,19\% nya di sumbang oleh Jawa Timur (Pusat data dan Informasi, 2018 dalam Wiraputra, Abdullah, \& Jyoti, 2019). Penduduk Indonesia rata-rata menyukai olahan singkong, karena mengandung karbohidrat atau sumber energi yang cukup tinggi, meskipun singkong memiliki kekurangan yaitu kadar protein dan vitamin yang rendah. Komposisi singkong per 100 gramnya mengandung Kalori 146,00 kal, Air $62,50 \mathrm{~g}$, Fosfor 40,00 mg, Karbohidrat 34,00 g, Kalsium 33,00 mg, Vitamin C 30,00 mg, Protein 1,20 g, Besi 0,70 mg, Lemak 0,30 g, Vitamin B1 0,06 $\mathrm{mg}$, dan Berat dapat dimakan 75,00 (Rahmadani, Alviansah, Sururi, \& Maghfiroh, 2018).

\section{Profil Mitra Ibu Rika}

Berdasarkan hasil komunikasi dengan mitra, berikut kami sampaikan gambaran analisis situasi dan permasalahan yang dihadapi mitra.

\section{Produksi}

Saat ini produksi Gethuk mitra sudah cukup variatif dengan rasa yang beragam. Tampilan produk juga sudah cukup menarik, namun saat ini mitra masih belum bisa memenuhi kebutuhan permintaan pasar dikarenakan peralatan produksi yang masih sederhana sekali. Produksi yang dihasilkan oleh mitra dapat digambarkan dalam tabel berikut:

Tabel 1 Produksi Mitra

\begin{tabular}{cccc}
\hline No & \multicolumn{1}{c}{ Produk } & $\begin{array}{c}\text { Kapasitas } \\
\text { Produksi }\end{array}$ & Pasar \\
\hline 1 & Roll Gethuk (4 rasa) & 5 box & $10 \mathrm{box}$ \\
\hline 2 & Gethuk Lindri & $2 \mathrm{~kg}$ & $10 \mathrm{~kg}$ \\
\hline
\end{tabular}

Dari tabel diatas, permintaan pasar masih cukup besar, permintaan meningkat terutama saat pandemi covid-19 dan anjuran pemerintah untuk bekerja dari rumah (work from home). Besarnya permintaan tersebut disikapi dengan penjualan preorder meskipun butuh waktu lama untuk memenuhi permintaan tersebut.

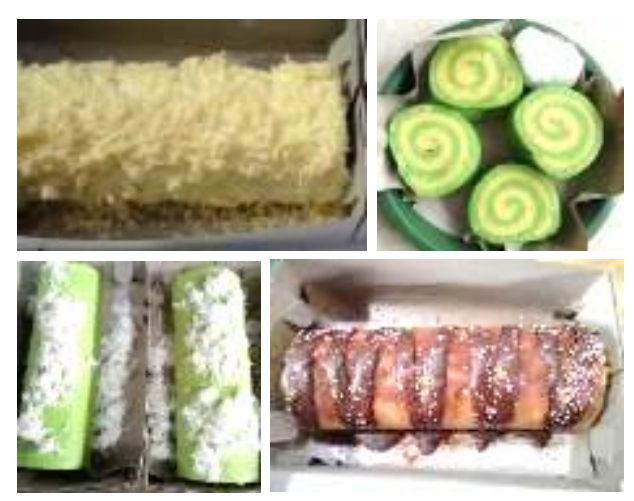

Gambar 1 Produk Gethuk Mitra

Peralatan yang digunakan oleh kedua mitra menggunakan peralatan manual yaitu dengan tongkat untuk menumbuk bahan yang hanya dibungkus plastik, yang akan digunakan kembali untuk proses produksi berikutnya menggunakan dengan tangan dan meratakan bahan dengan roll dari botol kaca roll botol yang dipakai berulang tanpa dicuci dengan bersih. Untuk dapat memenuhi permintaan pelanggan, diperlukan peralatan bertenaga mesin dengan motor penggerak sehingga produksi lebih cepat dan efisien. Mengingat saat ini dikerjakan sendiri, sehingga ada keterbaasan produksi setiap harinya.

Permasalahan lainnya adalah proses produksi masih dilakukan di lantai beralaskan tikar sehingga kurang bersih. Mitra masih kurang higienis untuk memproduksi makanan, tenaga produksi tidak menggunakan alat pelindung diri yang aman untuk makanan seperti masker, penutup rambut dan celemek. Bak untuk bahan dan bahan setengah jadi masih menggunakan plastik sehingga tidak higienis.

Lingkungan tempat produksi juga kurang bersih dan dekat dengan tempat cuci piring dan kamar mandi. Selain itu, seharusnya bahan singkong setelah dikupas harus dicuci ulang agar bersih dan dicuci kembali setelah dipotong kecil-kecil.

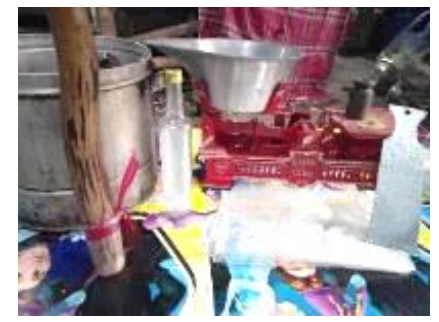

Ekonomi, Sosial, dan Budaya 
Gambar 2 Peralatan Produksi

Peralatan produksi yang digunakan mitra, sebagai berikut:

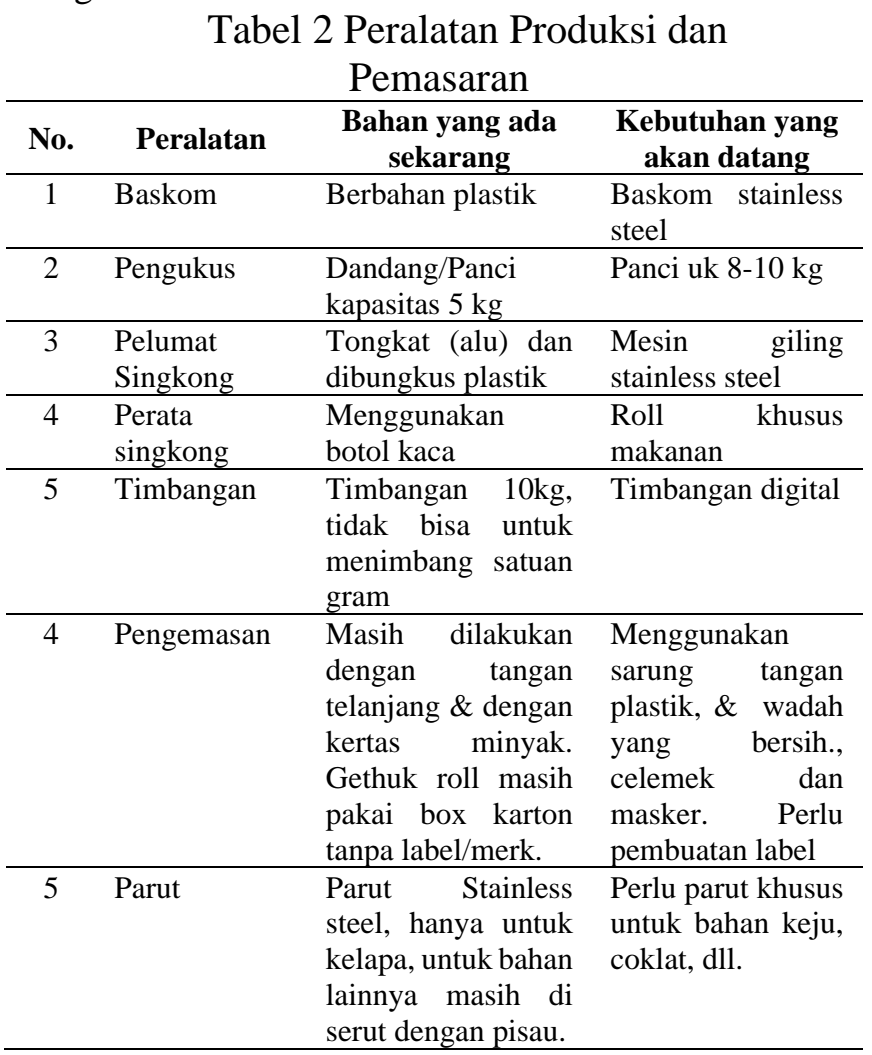

Bahan baku yang digunakan dalam proses produksi gethuk ini adalah singkong, gula pasir, pewarna makanan, kelapa, perasa (vanila, pandan, coklat dan lainnya). Adapun proses produksi gethuk diawali dengan singkong yang dikupas, dicuci bersih kemudian dipotong kecil-kecil, selanjutnya direbus/kukus selama kurang lebih 1 jam, kemudian dilumat dengan ditumbuk dg tongkat kayu. Singkong yang sudah ditumbuk ini kemudian dipisahkan untuk diberikan pewarna/perasa sesuai dengan permintaan pelanggan, setelah itu di ratakan/roll dengan botol kaca dan di gulung untuk membentuk roll gethuk seperti roll cake.

Adapun gambar proses produksi sebagai berikut :

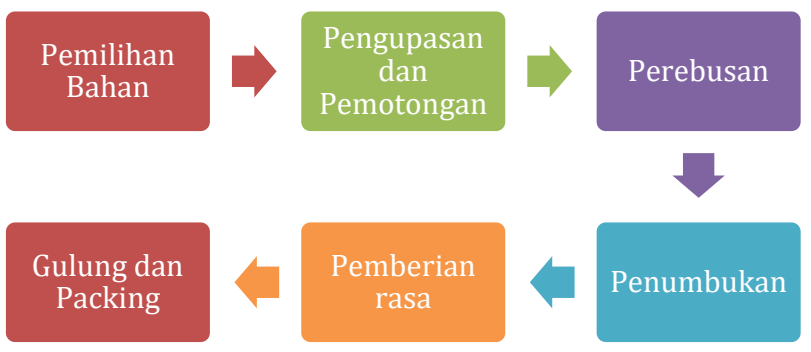

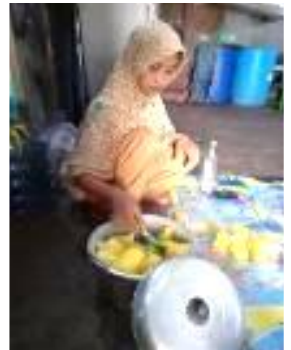
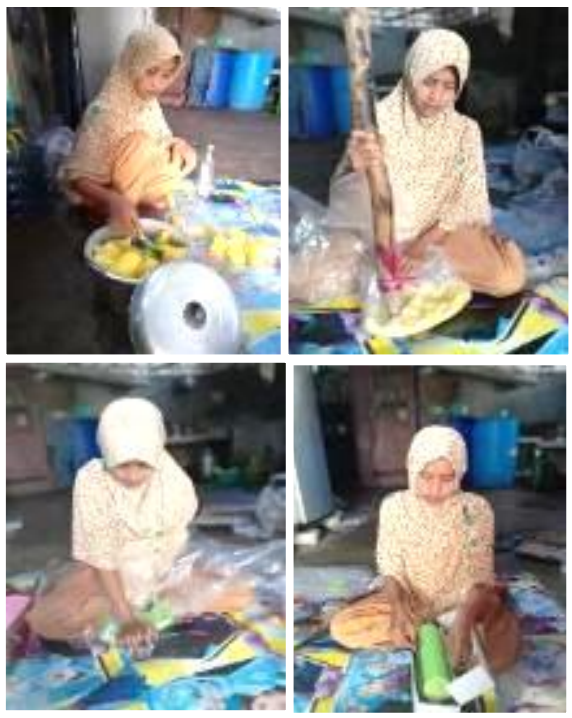

Gambar 3 Proses produksi mitra

\section{Manajemen}

Pemasaran produk gethuk saat ini sudah dilakukan secara daring dengan menggunakan media sosial facebook, instagram dan whatsapp, namun masih sangat terbatas pada teman atau keluarga saja, sehingga masih perlu perluasan pasar. Pengemasan produk juga masih sederhana dengan box karton untuk yang roll gethuk dan kertas minyak untuk yang dijual eceran/potongan. Seiring dengan adanya himbauan untuk bekerja dari rumah oleh pemerintah dan permintaan kudapan yang khas dari masyarakat, perlu peningkatan kapasitas produksi dan perbaikan kemasan agar tetap higienis, aman dan sehat sampai di tangan konsumen.

Proses distribusi saat ini juga masih dilakukan sendiri oleh mitra, biasanya dikirim setelah belanja di pasar atau dititipkan pada saudara. Mitra masih belum memiliki reseller yang membantu menjualkan produknya. Dalam hal ini diperlukan pelatihan pemasaran online dan offline.

Saat ini usaha ini masih dijalankan sendiri oleh mitra, tenaga yang membantu hanya suami atau anggota keluarga lainnya yang tidak sedang ada

\begin{tabular}{l|l} 
Ekonomi, Sosial, dan Budaya & 1098
\end{tabular} 
pekerjaan, hal ini dikarenakan memang usaha ini adalah usaha keluarga dan belum mampu menggaji orang lain. Permasalahan lainnya yang dihadapi mitra adalah masih minimnya pengetahuan tentang bagaimana menyajikan makanan yang menarik, bersih dan sehat.

Masalah lainnya yang juga umum dihadapi oleh pengusaha kecil adalah ketidaktertiban mereka untuk mencatat keuangan dalam laporan yang baik. Mitra sampai saat ini masih belum mencatat semua transaksi harian yang sudah dilakukan. Perencanaan produksi juga belum dilakukan atau hanya berdasarkan permintaan sehingga tidak ada perencanaan keuangan yang baik. Mitra sudah mampu menyusun harga pokok produksi dan harga jual yang baik, berikut harga jual produk :

Tabel 3 Harga Pokok Produksi dan Harga Jual Pokok Penjualan Gethuk

\begin{tabular}{|c|c|c|c|}
\hline No. & $\begin{array}{l}\text { Varian } \\
\text { Produk }\end{array}$ & HPP & HPJ \\
\hline 1 & $\begin{array}{ll}\text { Roll } & \text { Rasa } \\
\text { Pandan } & \\
\end{array}$ & Rp. 13.000,- & Rp. 25.000,- \\
\hline 2 & $\begin{array}{l}\text { Roll } \\
\text { Coklat }\end{array}$ & Rp. 16.500,- & Rp. 35.000,- \\
\hline 3 & Roll Rasa Keju & Rp. 22.500,- & Rp. 40.000,- \\
\hline 4 & Ecer / Potong & $\begin{array}{l}\text { Rp. } 13.000,- \\
\text { (15 potong) }\end{array}$ & $\begin{array}{l}\text { Rp. } 2.000,- \\
\text { (per potong) }\end{array}$ \\
\hline
\end{tabular}

Dari sisi kualitas dan kesehatan produksi, saat ini mitra sudah cukup baik dalam membuat produk menarik meskipun masih perlu belajar untuk terus membuat inovasi-inovasi produk lainnya. Selain itu, mitra juga perlu memahami proses produksi yang aman dan sehat. Berdasarkan pengamatan tim pengusul, mitra masih menggunakan peralatan yang kurang higienis untuk produk makanan, seperti tongkat yang hanya dibungkus plastik, yang akan digunakan kembali untuk proses produksi berikutnya, roll botol yang dipakai berulang tanpa dicuci dengan bersih, tenaga produksi tidak menggunakan alat pelindung diri yang aman untuk makanan seperti masker, penutup rambut dan celemek.

\section{Permasalahan Mitra}

Berdasarkan permasalahan yang dihadapi mitra dalam analisis situasi diatas, dapat dibedakan dalam 2 permasalahan utama yaitu permasalahan produksi dan manajemen. Permasalahan dalam produksi adalah ketidakmampuan mitra untuk meningkatkan kapasitas dan mutu produksi, sesuai dengan permintaan pasar yang meningkat karena proses produksi menggunakan cara manual yang tidak efisien. Sedangkan permasalahan manajemen diklasifikasi menjadi permasalahan pemasaran, manajemen, administrasi keuangan, serta manajemen mutu dan kesehatan. Berikut permasalahan yang dihadapi mitra:

1. Peralatan yang digunakan oleh kedua mitra menggunakan peralatan manual yaitu dengan tongkat untuk menumbuk dan meratakan bahan dengan roll dari botol kaca.

2. Proses produksi masih dilakukan di lantai beralaskan tikar sehingga kurang bersih.

3. Tidak menggunakan alat pelindung diri yang aman untuk makanan seperti masker, penutup rambut dan celemek. Bak untuk bahan dan bahan setengah jadi masih menggunakan plastik sehingga tidak higienis.

4. Lingkungan tempat produksi juga kurang bersih dan dekat dengan tempat cuci piring dan kamar mandi.

5. Proses pengolahan bahan singkong setelah dikupas harus dicuci ulang agar bersih dan dicuci kembali setelah dipotong kecil-kecil.

6. Pemasaran produk gethuk saat ini sudah dilakukan secara daring dengan menggunakan media sosial facebook, instagram dan whatsapp, namun masih sangat terbatas pada teman atau keluarga saja, sehingga masih perlu perluasan pasar.

7. Pengemasan produk juga masih sederhana dengan box karton untuk yang roll gethuk dan kertas minyak untuk yang dijual eceran/potongan.

8. Proses distribusi saat ini juga masih dilakukan sendiri oleh mitra, biasanya dikirim setelah belanja di pasar atau dititipkan pada saudara. Mitra masih belum memiliki reseller yang membantu menjualkan produknya. Dalam hal ini diperlukan pelatihan pemasaran online dan offline.

9. Saat ini usaha ini masih dijalankan sendiri oleh mitra, tenaga yang membantu hanya suami atau anggota keluarga lainnya yang tidak sedang ada pekerjaan, hal ini dikarenakan memang usaha ini adalah usaha keluarga dan belum mampu menggaji orang lain.

10. Permasalahan lainnya yang dihadapi mitra adalah masih minimnya pengetahuan tentang

$$
\text { Ekonomi, Sosial, dan Budaya }
$$


bagaimana menyajikan makanan yang menarik, bersih dan sehat.

11. Mitra sampai saat ini masih belum mencatat semua transaksi harian yang sudah dilakukan.

12. Perencanaan produksi juga belum dilakukan atau hanya berdasarkan permintaan sehingga tidak ada perencanaan keuangan yang baik.

13. Mitra sudah cukup baik dalam membuat produk menarik meskipun masih perlu belajar untuk terus membuat inovasi-inovasi produk lainnya. Selain itu, mitra juga perlu memahami proses produksi yang aman dan sehat.

\section{Solusi dan Target Luaran}

Berdasarkan permasalahan mitra diatas dan dikarenakan banyaknya permasalahan yang ada, maka tim pengusul memprioritaskan beberapa permasalahan yang akan diselesaikan bersama mitra, solusi dan target luaran melalui program ini, yaitu: (1) pengadaan mesin giling dan roll yang khusus untuk makanan; (2) pengadaan bak stainless steel; (3) perlu pengadaan peralatan pelindung diri, pelatihan dan pendampingan produksi sehat; (4) perlu pelatihan dan pendampingan produksi diatas meja yang bersih; (5) perlu pelatihan dan pendampingan produksi sehat; (6) perlu pelatihan dan pendampingan produksi sehat; (7) perlu pelatihan dan pendampingan pembuatan label produksi dan kemasan yang sehat dan aman untuk makanan; (8) pelatihan inovasi produk; (9) pelatihan pencatatan keuangan usaha mikro dan perencanaan produksi; dan (10) pelatihan pencatatan keuangan usaha mikro dan perencanaan produksi.

\section{METODE}

Metode pelaksanaan kegiatan Program Pemberdayaan Masyarakat (PPM) mengacu pada tujuan kegiatan yang telah diterapkan. Adapun tahapan atau langkah-langkah dalam melaksanakan solusi yang ditawarkan untuk mengatasi permasalahan mitra sebagai berikut : (1) melakukan koordinasi dengan mitra dan penyedia kebutuhan program; (2) pengadaan mesin giling dan roll yang khusus untuk makanan; (3) menyelenggarakan pelatihan dan pendampingan produksi sehat, pembuatan label dan kemasan yang sehat dan aman serta inovasi produk untuk makanan; (4) pengadaan peralatan pelindung diri untuk produksi makanan; (5) pengadaan bak stainless steel; dan (6) menyelenggarakan Pelatihan dan pendampingan pencatatan keuangan usaha mikro, perencanaan produksi dan inovasi produk.

\section{HASIL DAN PEMBAHASAN}

Berikut hasil dari pelaksanan program pemberdayaan masyarakat ni:

\section{Pra Program}

Sebelum kegiatan dilaksanakan, tim pelaksana terlebih dahulu berkoordinasi dengan mitra terkait pembuatan kesepakatan permasalahan prioritas yang akan diselesaian, jadwal program kegiatan, pengadaan peralatan dan pembagian peran tim pelaksana.

Kegiatan ini dilakukan di beberapa tempat, yaitu di tempat kegiatan/rumah mitra, yaitu di Dusun Kedungsekar Lor, Desa Kedungsekar Kecamatan Benjeng Kabupaten Gresik dan di Kampus UWP Jl. Raya Benowo No. 1-3 Surabaya.

\section{Pelaksanaan Program}

Sebelum kegiatan dilaksanakan, tim pelaksana terlebih dahulu berkoordinasi dengan mitra terkait

\section{a. Pengadaan peralatan}

Peralatan yang digunakan mitra sebelum program ini sebagaimana pada Gambar 2 dan Tabel 2 diatas, masih sangat sederhana dan kurang sehat (belum memenuhi standar kesehatan pangan). Pengadaan peralatan usaha yang diberikan keada mitra, antara lain; mesin giling dan roll yang khusus untuk makanan berbahan baku stanless steel; bak stainless steel; peralatan pelindung diri (masker, celemek, dan sarung tangan)

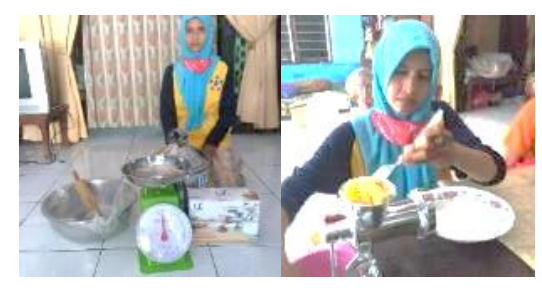

Ekonomi, Sosial, dan Budaya 
Gambar 1 Pengadaan alat produksi dan ujicoba alat

\section{b. Pelatihan dan pendampingan produksi sehat}

Pelatihan produksi sehat dilakukan 1 (satu) kali yaitu dengan praktikum langsung. Pelatihan ini dimulai dari proses pemilihan bahan baku singkong yang baik, pencucian, pemasakan, penggilingan, pemberian rasa dan proses pencetakan produk gethuk. Produk yang ada sebelum pelatihan menggunakan pewarna dari pabrikan, diarahkan untuk menggunakan pewarna alami seperti penggunaan daun pandan, buah naga, wortel, dll. Proses penggilingan sebelumnya menggunakan batang kayu/Alu saat ini menggunakan alat penggilingan berbahan staninless steel sehingga aman buat makanan, selain itu selama proses produksi juga dilatih menggunakan peralatan yang aman untuk makanan, mengunakan celemek, penutup rambut, masker dan sarung tangan. Selain itu proses produksi juga sudah dilakukan di atas meja, sehingga jauh dari lantai .

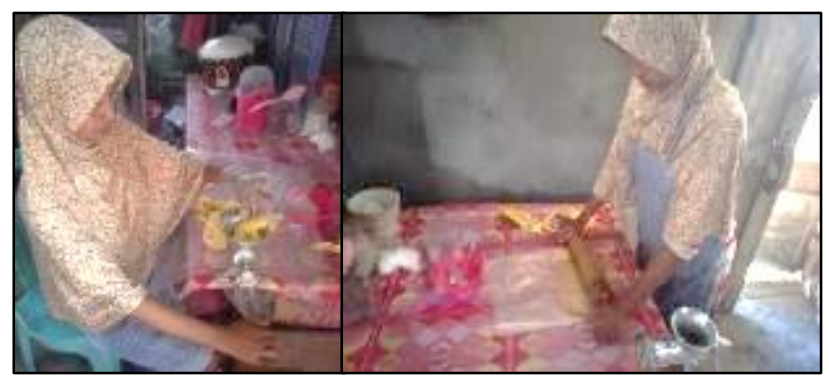

Gambar 2 Pelatihan Produksi Sehat

Pasca pelatihan diadakan pendampingan produksi sehat, hal ini dilakukan untuk memastikan bahwa materi pelatihan dipraktekkan oleh mitra dan dapat menjadi kebiasaan bagi mitra untuk memperhatikan faktor kesehatan dalam proses produksi pangan.

\section{c. Pelatihan dan Pendampingan label dan kemasan}

Kemasan yang dimiliki oleh mitra saat ini sudah cukup baik, dimana berbahan kertas karton dengan ketebalan 360gsm, terdapat bagian transparan dari bahan plastik diatas, sehingga produk terlihat dari luar serta ada lapisan dari kertas minyak didalam, sehingga produk gethuk tidak menempel langsung pada kemasan karton. Pelatihan yang diberikan berupa pemberian label pada kemasan agar konsumen mengetahui produk dimaksud, saat ini label yang dibuat masih belum ada informasi tentang produk tersebut, komposisi, tanggal produksi dan kadaluarsa, rasa, berat bersih. Berikutnya akan disiapkan label yang memenuhi ketentuan produk pangan siap makan namun dengan memperhatikan harga kemasan yang tidak memberatkan konsumen.

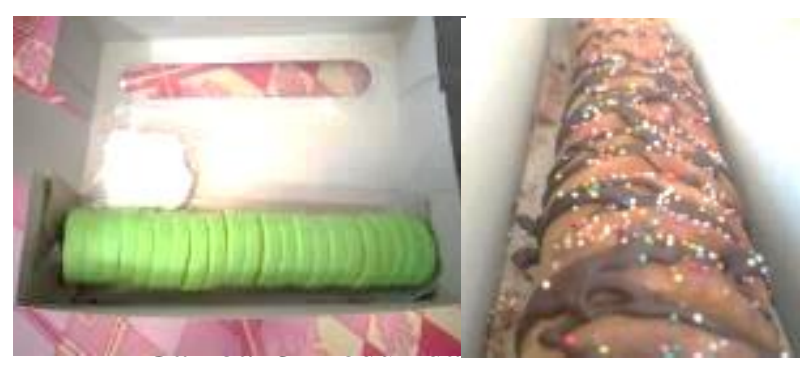

\section{d. Pengoptimalan pemasaran melalui media sosial}

Saat sebelum program pemberdayaan masyarakat ini, mitra sudah memiliki akun di media sosial terutama Instagram dengan akun @gethukku_loh, namun jarang melakukan update dan unggah konten, sehingga terkesan tidak ada produksi, selain itu konten yang diunggah juga kurang menarik dan caption belum mampu menarik pelanggan baru untuk membeli produk.

Pelatihan yang diberikan adalah membuat konten gambar dan video yang baik, komunikatif dan menerik bagi konsumen dengan pendekatan hipnoselling. Caption yang diberikan juga dibuat agar konsumen tertarik untuk ingin mengetahui lebih jauh tentang produk gethuk ini. Selain itu juga, muatan konten dan caption juga harus mampu memberikan edukasi kepada follower tentang manfaat gethuk ini. 


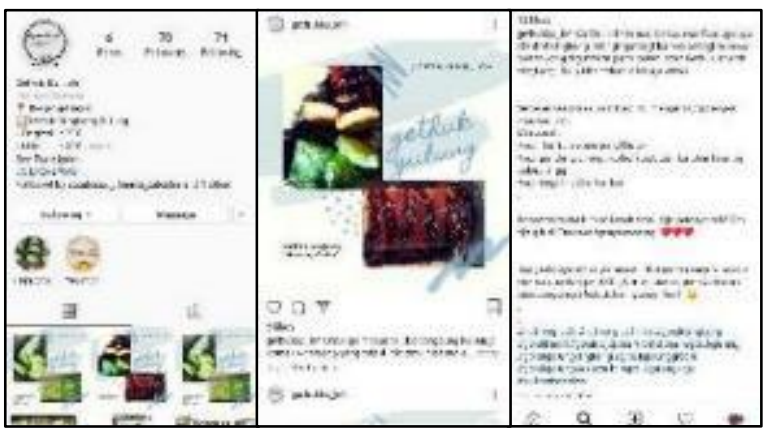

Gambar 4 Konten dan caption akun Instagram @ gethukku_loh

\section{e. Pelatihan inovasi produk}

Pelatihan inovasi produk diberikan terutama pada rasa dan bentuk produk. Pelatihan diberikan sebanyak 1 (satu) kali. Saat ini mitra masih mencoba untuk membuat varian rasa yang berbeda dengan tetap mempertahankan dari perasa dan pewarna alami. Adapun varian rasa yang saat ini ada adalah rasa coklat, keju, pandan, wortel dan mix. Untuk varian bentuk mitra berencana membuar bentuk yang menarik bagi anak-anak dengan cetakan.

\section{f. Pelatihan keuangan usaha}

Pelatihan ini diupayakan agar mitra mampu menghitung keuangan usahanya sehingga dapat diketahui laba/rugi. Materi yang disampaikan dikemas sesederhana mungkin sehingga mudah dipahami oleh mitra. Materi pelatihan keuangan ini, antara lain; menghitung harga pokok penjualan, pencatatan transaksi pembelian dan penjualan, menghitung bahan dalam proses, persediaan, pemisahan keuangan usaha dan keuangan rumah tangga serta menghitung laba/rugi.

Pasca pelatihan, dilakukan pendampingan untuk memastikan mitra menjalankan secara rutin materi yang sudah diberikan. Dari pelatihan ini, mitra sudah mampu menghitung harga pokok produksi, disiplin mencatat transaksi usaha, dan sudah bisa menghitung laba/rugi usaha.

\section{Pasca Program}

Untuk memastikan semua program pelatihan dan pendampingan berjalan dan berdampak, diadakan evaluasi dan pendampingan lanjutan kepada mitra. Evaluasi dan pendampingan lanjutan ini dilakukan untuk memastikan mitra merasa nyaman dengan pola produksi sehat seperti yang diajarkan, menjadikan produksi sehat sebagai budaya dalam berwirausaha pangan, terus melakukan inovasi produksi

Dampak program ini yang bisa dirasakan oleh mitra adalah adanya peningkatan penjualan sebesar 15\%, hal ini menurut mitra dikarena pengoptimalan pemasaran melalui instagram dan whatsapp.

\section{KESIMPULAN}

Berdasarkan hasil dan pembahasan diatas, dapat disimpulkan bahwa Program Pemberdayaan Masyarakat ini cukup berdampak bagi mitra, yaitu adanya peningkatan pendapatan sebesar $15 \%$. Kegiatan yang dilakukan selama program, antara lain berkoordinasi dengan mitran, pengadaan peralatan, pelatihan dan pendampingan produksi sehat, pelatihan dan pendampingan label dan kemasan, pengoptimalan pemasaran melalui media sosial, pelatihan inovasi produk, pelatihan keuangan usaha, dan pasca program melalui evaluasi dan pendampingan lanjutan untuk memastikan mitra merasa nyaman dengan pola produksi sehat seperti yang diajarkan.

\section{UCAPAN TERIMAKASIH}

Ucapan terimakasih disampaikan kepada Universitas Wijaya Putra dan Lembaga Penelitian dan Pengabdian Kepada Masyarakat Universitas Wijaya Putra yang telah memberikan pendanaan dan dukungan dalam pelaksanaan program pemberdayan masyarakat ini. Ucapan terima kasih juga kami sampaikan kepada Mitra PPM dan Pemerintah Desa Kedungsekar Lor Kecamatan Benjengs Kabupaten Gresik. 


\section{REFERENSI}

BPS, K. G. (2019). Kecamatan Benjeng Dalam Angka 2019. Kabupaten Gresik: Badan Pusat Statistik Kabupaten Gresik.

Rahmadani, L. S., Alviansah, N. R., Sururi, B. K., \& Maghfiroh, I. L. (2018). Inovasi serta Pelatihan Pengolahan Singkong sebagai Upaya Menumbuhkan Jiwa Kewirausahaan Masyarakat Dusun Sumber Desa Planjan Kecamatan Saptosari Kabupaten Gunung
Kidul, 1, 401-404.

Wiraputra, D., Abdullah, K., \& Jyoti, M. D. (2019). Review: Pengembangan Produk Berbasis Ubi kayu dalam Industri Pangan Review : Product Development of Cassava in Food Industry. Majalah Teknologi Agro Industri (Tegi), 11(2), 44-53. 